\title{
Thiazolidinedione 최신지견
}

\section{김원준}

울산대학교 의과대학 강릉아산병원 내분비내과

\section{Recent Perspective on Thiazolidinedione}

\begin{abstract}
Won Jun Kim
Division of Endocrinology and Metabolism, Department of Internal Medicine, Gangneung Asan Hospital, University of Ulsan College of Medicine, Gangneung, Korea
\end{abstract}

\begin{abstract}
Thiazolidinedione (TZD) is an insulin sensitizer that improves insulin resistance in the adipose tissue, liver, and muscles and has a pancreas-protective effect while inhibiting gluconeogenesis. Its other advantages include a glucose lowering effect, its durability, cardiovascular benefit, and recent evidence in nonalcoholic fatty liver disease and dementia. However, there are also concerns about fluid retention/ edema/heart failure, bladder cancer, and fractures with TZD use. TZD can still be a useful option for diabetes treatment when calculating risk versus benefit, but appropriate selection of patients is needed.
\end{abstract}

Keywords: Diabetes mellitus, type 2; Hypoglycemic agents; Pioglitazone; Thiazolidinediones

\footnotetext{
$$
\text { 서론 }
$$

싸이아졸리딘다이온(thiazolidinedione, TZD)은 근육, 지 방세포에서 인슐린민감성을 개선시키고, 간에서 포도당생 성을 감소시키는 약제이다. 현재 국내에서는 피오글리타

존(pioglitazone), 로베글리타존(lobeglitazone)이 사용 가 능하다. 과거 TZD 계열 약제 중 하나였던 로시글리타존 (rosiglitazone)이 2007년 심혈관질환 위험을 증가시킨다는 보고 이후 시장에서 철수되기도 했지만, 2009년 RECORD (Rosiglitazone Evaluated for Cardiac Outcomes and

Corresponding author: Won Jun Kim

Division of Endocrinology and Metabolism, Department of Internal Medicine, Gangneung Asan Hospital, University of Ulsan College of Medicine, 38 Bangdonggil, Sacheon-myeon, Gangneung 25440, Korea, E-mail: kozmozmananaver.com

Received: Apr. 26, 2021; Accepted: May 2, 2021

This is an Open Access article distributed under the terms of the Creative Commons Attribution Non-Commercial License (http://creativecommons.org/licenses/by$\mathrm{nc} / 4.0 /$ ) which permits unrestricted non-commercial use, distribution, and reproduction in any medium, provided the original work is properly cited.

Copyright (C) 2021 Korean Diabetes Association
} 
Regulation of Glycaemia in Diabetes) 연구 결과에서 심혈 관질환을 증가시키지 않는다는 결과를 보여 2013년 미국 식 품의약국(U.S. Food and Drug Administration, FDA)은 사 용 제한을 철회하였다[1]. 국내 당뇨병 진료지침에서는 TZD 는 당뇨병 치료약제 중에서 효과는 강하고, 심뇌혈관질환 에 이득이 있으며, 저혈당 위험은 적으나 체중이 증가할 수 있는 약제로 정리하고 있다[2]. 당뇨병 약제 중에 메트포민, dipeptidyl peptidase-4 (DPP4) 억제제, 설포닐유레아 및 인 슐린과 병용요법이 가능하다.

\section{본론}

\section{1. 작용기전}

PPAR (peroxisome proliferator activated receptor)은 고 등 생물의 세포 분화, 발달 및 신진 대사 조절에 역할을 하고 증식을 유도하는 전사인자인데, 피오글리타존과 로베글리타 존은 $\mathrm{PPAR}-\gamma$ 와 $\mathrm{PPAR}-\alpha$ 에 대한 작용제로서 지방조직과 근 육이나 간에서 인슐린저항성을 개선시키는 작용이 있다. 이 중 $\mathrm{PPAR}-\gamma$ 는 지방조직에 많이 분포되어 있다.

$\mathrm{TZD}$ 계열 약제는 주로 PPAR- $\gamma$ 수용체를 통해 지방세포 의 분화를 촉진시켜서 전지방세포에서 지방세포의 분화를 유 도하고, 포도당 수용체의 유전자 발현 증가, 지질단백 지질 분해효소의 발현 유도 및 아디포넥틴의 증가를 가져온다. 또 한 $\mathrm{TZD}$ 는 렙틴 및 종양괴사인자- $\alpha, \mathrm{PAI}-1$ (plasminogen activator inhibitor-1), interleukin 6와 같은 염증을 매개하 는 인자의 발현을 감소시킨다. 그 결과 고혈당을 개선시키고 인슐린 농도, 중성지방 농도 및 유리지방산 농도를 감소시킨 다. 조직별로 $\mathrm{TZD}$ 는 지방조직에서 포도당 산화와 지방형성 을 촉진하고, 근육에서 당 흡수를 증가시키며 간에서 포도당 신생성을 감소시킨다[3].

$\mathrm{TZD}$ 는 췌장 베타세포를 보호하고 유리지방산을 감소시키 면서 2형당뇨병에서 베타세포기능을 회복시켰다. 당뇨병전단 계의 Otsuka Long-Evans Tokushima Fatty (OLETF) rat 에 $\mathrm{TZD}$ 를 투여한 결과 당뇨병의 발생을 낮추었으며, 피오글
리타존을 비만한 당뇨병 모델인 $\mathrm{db} / \mathrm{db}$ mouse에 투여한 결과 산화스트레스 감소와 함께 인슐린분비능이 회복되면서 췌장 베타세포를 보호하였다[4]. 또한 TZD 계열 약제는 인간의 췌 장 베타세포를 세포자멸사로부터 보호하였고, 2형당뇨병 환 자들은 $\mathrm{TZD}$ 를 복용한 결과 혈당이 조절되면서 베타세포 기 능이 개선되었다[5,6].

\section{2. $\mathrm{TZD}$ 의 혈당 강하 효과}

$\mathrm{TZD}$ 는 공복과 식후 고혈당을 모두 감소시킨다. $\mathrm{TZD}$ 는 수주에서 수개월 내에 혈당을 개선시키고, 인슐린저항성을 개 선하며 내인성 인슐린이 더 효과적으로 작용할 수 있도록 도 와준다. 베타세포 보호 기능으로 TZD는 혈당조절지속성이 다른 메트포민, 설포닐유레아와 같은 경구혈당강하제에 비해 우수하며, 인슐린분비능은 체중 및 지방량이 증가할수록 더 반응이 좋았다고 한다[6,7].

한 임상 연구에 따르면 피오글리타존을 26주 단독요법으 로 위약군과 비교했을 때 공복혈당이 $34 \mathrm{mg} / \mathrm{dL}$ (15 mg 사 용), $36 \mathrm{mg} / \mathrm{dL}$ (30 mg 사용) 감소했고, 당화혈색소는 0.9\% (15 mg), 1.1\% (30 mg) 감소했다[8]. 메트포민과 병용했을 때 16 주 치료 후에 피오글리타존 $30 \mathrm{mg} / \mathrm{day}$ 경우 공복혈당 38 $\mathrm{mg} / \mathrm{dL}$, 당화혈색소 $0.8 \%$ 가 감소하는 효과가 있었다[9]. 설 포닐유레아와 병용한 경우에는 공복혈당이 $34 \mathrm{mg} / \mathrm{dL}$ (15 $\mathrm{mg}), 52 \mathrm{mg} /$ day $(30 \mathrm{mg}$ ) 감소했으며, 당화혈색소는 $0.8 \%$ $(15 \mathrm{mg}), 1.2 \%$ (30 mg) 감소했다. 인슐린과 병용했을 때 당 화혈색소는 $1 \%$ (15 mg), 1.3\% (30 mg) 호전되었다[10].

피오글리타존은 인슐린저항성을 개선하고 인슐린요구량을 줄여주어 인슐린분비를 촉진해야 하는 베타세포의 부담을 덜 어준다. 또한 인슐린민감성이 증가함에 따라 주사로 투여해 야 할 인슐린의 양을 줄일 수 있는데, 한 연구에서 하루에 평 균 56단위의 인슐린 주사를 맞는 222 명의 환자에게 피오글리 타존을 추가한 경우 위약군에 비해 2주 후 의미 있는 인슐린 용량의 감소가 있었고, 20 주 동안 같은 혈당조절을 유지하면 서도 평균 12 단위(21.5\%) 정도 감량을 할 수 있었다[11].

로베글리타존 $0.5 \mathrm{mg}$ 을 단독요법으로 24주간 투여 후 위 
약군과 비교한 결과 당화혈색소가 $0.6 \%$ 더 유의하게 감소하 였고 인슐린저항성 지표가 호전되었다[12]. 또한 로베글리타 존과 메트포민과의 병용에서는 24주간 피오글리타존 $15 \mathrm{mg}$ 과 메트포민을 병용한 대조군과 비교할 때 두 군에서 모두 당화혈색소가 $0.74 \%$ 감소되어 대등한 효과를 보였다[13]. 당 화혈색소 9 $12 \%$ 사이의 당뇨병 치료를 받지 않은 100 명의 환자들에게 로베글리타존, 메트포민과 시타글립틴을 12 개월 간 3제 병용한 그룹은 메트포민과 설포닐유레아를 병용한 100 명의 그룹보다 혈당 강하 효과와 저혈당에 대한 안정성 및 베타세포 기능의 회복을 입증했다[14].

\section{3. $\mathrm{TZ}$ 의 혈당 강하 이외의 다른 효과}

\section{1) 심혈관질환 예방 효과}

심혈관질환 예방 효과를 증명한 최초의 대규모 연구는 PROactive (PROspective pioglitAzone Clinical Trial In macroVascular Events) 연구이다. 대혈관합병증이 있는 2형 당뇨병 환자 5,238명을 대상으로 피오글리타존 $45 \mathrm{mg}$ 과 위 약을 평균 34.5개월 투여한 이 연구에서 모든 사망률, 비치 명적 심근경색, 뇌졸중, 급성관상동맥증후군, 혈관 중재술 시 행, 발목절단 등을 모두 합친 1차 종말점에는 양 군 간에 의 미 있는 차이를 보이지 못했으나 모든 사망률, 비치명적 심 근경색, 뇌졸중을 포함하는 2차 종말점에는 유의한 차이를 보였다(hazard ratio $=0.84 ; 95 \%$ confidence interval [CI] 0.72 0.98) [15]. 또한 RIS (Insulin Resistance Intervention after Stroke) trial에서 당뇨병 기왕력은 없지만 인슐린저항성 이 있는 일과성허혈발작 또는 뇌졸중 환자를 위약군과 평균 4.8 년 기간 동안 비교한 결과, 피오글리타존은 뇌졸중이나 심 근경색을 $24 \%$, 당뇨병 발생은 $52 \%$ 감소시켰다[16]. 메타분 석에 영향력이 매우 큰 PROactive 연구를 제외한 피오글리타 존 연구를 메타분석한 결과에서는 모든 원인에 의한 사망률 감소(odds ratio $=0.3,95 \%$ CI 0.14 0.63)가 새롭게 관찰되 었다. 피오글리타존의 역학연구 결과들은 TZD의 인슐린저항 성 개선 효과가 심혈관 보호 효과를 이끌 수 있음을 시사하 였다. 이 가설은 $\mathrm{TZD}$ 가 경동맥내중막두께 감소, 혈관 내피세
포 기능 호전, 이상지질혈증 개선, 혈압 감소, 섬유소 용해 및 응고 매개 변수의 호전들을 보여 준 일련의 연구 결과들에 뒷 받침되었다[17].

Nissen의 메타분석결과가 2007년에 The New England Journal of Medicine에 발표되면서 로시글리타존의 심근경색 증 위험성 때문에 로시글리타존은 2010년 유럽시장에서 퇴출 되었고 2011년 미국시장에서의 사용이 제한되었다가, 2009년 오픈 라벨 연구인 RECORD 연구 결과에서 메트포민이나 설 포닐유레아보다 심혈관질환을 증가시키지 않는다는 결과를 보여 FDA는 2013년에 사용 제한을 철회하였다[1]. 반면 피오 글리타존은 2형당뇨병 환자를 대상으로 한 많은 연구에서 일관되게 심혈관질환의 위험을 낮추고 동맥경화증 진행을 예 방하는 것으로 보고되고 있다.

\section{2) 지질 개선}

피오글리타존과 로시글리타존의 6건의 무작위 시험 연구 들을 종합한 연구에서, 피오글리타존을 사용했을 때 low density lipoprotein (LDL) 콜레스테롤 수치는 일반적으 로 일정하게 유지되는 반면, 로시글리타존 연구에서는 $\mathrm{LDL}$ 콜레스테롤 수치가 8 16\% 증가하였다[18]. High density lipoprotein (HDL) 콜레스테롤 수치는 두 약물 모두 약 10\% 증가했다. 피오글리타존은 중성지방 호전과 함께 $\mathrm{HDL}$ 및 $\mathrm{LDL}$ 입자 크기의 개선을 보였다[19]. 로베글리타존에서도 중 성지방과 유리지방산이 감소되었고, 밀도 높은 $\mathrm{LDL}$ 콜레스테 롤 및 $\mathrm{HDL}$ 콜레스테롤도 호전되었다[12].

\section{3) 지방간}

비알코올지방간에서는 생활습관교정 및 체중감량이 필수 적이지만, 당뇨병 경구치료제 중에 인슐린민감제가 도움이 된 다고 알려져 있다. 2형당뇨병에서 많이 사용되는 메트포민 은 간 조직학적 소견을 개선시키지는 못했지만[20], 피오글 리타존을 생검으로 입증된 비알코올지방간염(nonalcoholic steatohepatitis, NASH)에 투여한 3개의 임상 연구들을 종합 한 결과, 피오글리타존이 투여된 환자군(137명)은 위약군(137 명)에 비해 조직학적 섬유화가 호전되었다(odds ratio $=1.7$, 
95\% CI 1.02 2.77) [21]. 또한 다른 연구들에서도 간수치, 염 증 및 지방간을 개선하였다[22,23]. 로베글리타존은 고지방 식이로 유도한 비만한 mouse에게 4주간 투여한 결과 간에 서의 당신생과 관련된 유전자 발현 감소, $\mathrm{PPAR}-\alpha$ 의 유도 및 $\mathrm{PPAR}-\gamma$ 의 전사후 변형, 지방산 $\beta$-산화와 관련된 유전자 발 현 증가 및 지방간의 조직학적인 호전을 보였다[24]. 로베글리 타존은 fibroscan으로 확인된 비알코올지방간을 가진 2형당 뇨병 환자 50명에게 24주간 투여 후 혈당 조절과는 별개로 간수치 및 fibroscan의 지방간 점수 $(313.4 \mathrm{~dB} / \mathrm{m}$ 에서 297.8 $\mathrm{dB} / \mathrm{m}, P=0.016)$ 가 호전되었다[25].

\section{4) 치매}

2형당뇨병이 동반된 경우 치매의 위험이 높고, 당뇨병의 조 절은 치매 발생에 영향을 미칠 수 있다. 2형당뇨병에서 관찰되 는 여러 대사 이상들(주로 혈당, 혈압 및 지질)을 엄격하게 조 절하는 경우 치매의 위험을 감소시킬 것으로 생각한다. 2형당 뇨병과 치매의 공통적인 병인으로는 인슐린저항성과 염증이 있으며 저혈당도 치매의 위험인자가 될 수 있다. 따라서 인슐 린감작제이며 항염증작용을 가지면서 상대적으로 저혈당 위험 이 없는 경구 혈당강하제인 TZD는 알츠하이머병/혈관성 치 매 모두의 발병 위험을 낮출 것으로 가설을 세울 수 있다. 몇 몇 연구들에서는 $\mathrm{TZD}$ 의 알츠하이머병 증상 개선 확인에 실패 하였지만, Watson 등[26]은 기억상실형 인지기능장애 또는 경 증의 알츠하이머병 환자들에게 6개월간 로시글리타존을 투 여 후 인지기능의 호전과 알츠하이머병 관련 지표인 아밀로 이드-베타 농도의 안정화를 보고하였다. Heneka 등[27]은 2004 2010년 14만 명 이상의 60세 이상 독일 국민을 대상으 로 관찰한 결과, 당뇨병이 없는 그룹과 비교할 때 장기간 피 오글리타존을 치료받은 당뇨병 그룹이 치매의 상대적 위험도 가 오히려 $47 \%$ 더 낮았고 피오글리타존을 치료받지 않은 당 뇨병 환자에서 치매 위험이 $23 \%$ 더 높았다.

\section{5) 2형당뇨병의 예방}

당뇨병전단계는 위험인자를 동반하여 당뇨병 발생 위험이 높은 상태를 의미한다. 당뇨전단계 환자에게 적극적 생활습
관 중재를 통해 당뇨병을 예방할 수 있음이 알려져 있지만, 약물중재를 통한 당뇨병 위험인자 관리 역시 당뇨병 발생 위 험을 유의하게 줄였다. 현재까지 TZD를 포함한 메트포민, 알 파글루코시다아제억제제, 글루카곤유사펩티드-1수용체작용 제 등의 혈당강하제, 그리고 올리스타트, 로카세린 등 비만치 료제의 당뇨병 예방효과가 확인되었다[2]. 공복혈당장애 혹은 내당능장애를 대상으로 한 DREAM (Diabetes REduction Assessment with ramipril and rosiglitazone Medication) trial에서는 로시글리타존 $8 \mathrm{mg}$ 를 3년간 투여한 군이 대조군 보다 $60 \%$ 당뇨병 발생이 감소되었고, 체질량지수 $25 \mathrm{~kg} / \mathrm{m}^{2}$ 이상의 내당능장애를 대상으로 한 ACT Now (Actos Now for the Prevention of Diabetes) 연구에서 피오글리타존 45 $\mathrm{mg}$ 투여군이 대조군보다 $72 \%$ 당뇨병 발생이 감소되었다 $[28,29]$.

\section{4. $\mathrm{TZD}$ 의 부작용}

1) 체중증가

$\mathrm{TZD}$ 계열 약물 투여로 약 2 3 kg 정도의 체중증가가 발 생하는데, 로베글리타존 단독요법의 경우에도 위약대비 1.5 $\mathrm{kg}$ 체중증가가 관찰되었다[1]. 설포닐유레아, 인슐린과의 병용 시에는 체중증가 위험이 높아질 수 있다. 체중증가 때 가장 문제가 되는 부분은 내장지방이지만, TZD에 의한 지방 증가 는 인슐린저항성과 관련된 내장지방은 오히려 줄어들고 몸에 해가 되지 않는 피하지방의 증가가 관찰된다.

\section{2) 체액 저류/부종}

부종은 피오글리타존 단독요법의 경우 대조군의 $1.2 \%$ 보다 높은 $4.8 \%$ 에서 관찰되며 인슐린과 병용요법 시에는 대조군 의 $7.0 \%$ 보다 높은 $15.3 \%$ 에서 발생한다. 혈장량 증가로 인한 희석효과로 인해 약물 투여 4 12주 후에 혈색소 및 적혈구용 적률의 감소가 발생하며 그 이후에는 큰 변화는 없다[1]. 특 히 인슐린이나 설포닐유레아와 병용요법 시에 부종 발생이 더 증가하는 것으로 보고되어 있다. 그러나 TZD로 인한 울혈성 심부전은 수분 저류로 인한 것으로 생각되고 있으며, 심실의 
수축이나 이완기능에는 영향이 없는 것으로 보고된다. TZD 로 인한 수분 저류는 이뇨제와 TZD 용량 감량으로 조절이 가능하다. 이노제와 TZD 용량 감량만으로 부종이 해결되지 않을 경우에는 $\mathrm{TZD}$ 를 중단해야 한다. $\mathrm{TZD}$ 는 신장과 장에 서 ion transport를 변화시키고, 미세혈관 투과성을 증가시켜 부종을 일으킨다[30]. 또한 신장 피질 집합관에서 수분의 재 흡수를 증가시키는 것을 부종의 한 원인으로 보고 있다.

\section{3) 심부전}

PROactive 연구에서는 TZD 복용이 심혈관질환과는 관 계 없으나 심부전의 위험성이 증가함을 보였다. 심각한 심부 전은 피오글리타존 복용군(5.7\% 발생)에서 대조군 $(4.1 \%$ 발 생)보다 더 의미 있게 많이 발생했다[31]. 최근의 메타분석 결 과에서도 피오글리타존 복용 환자군이 대조군보다 $47 \%$ 심 부전이 더 발생하였고, 심부전으로 인한 입원도 $48 \%$ 더 높았 다[32]. FDA와 American Diabetes Association/American Heart Association에서는 심부전 환자(New York Heart Association [NYHA] III or IV)나 심부전의 과거력이 있는 환 자에서 TZD 사용을 금기로 하고 있으며, NYHA I, 픠읨부 전 환자에서는 $\mathrm{TZD}$ 를 조심스럽게 저용량으로 시작해볼 수 있다고 권고하고 있다.

\section{4) 방광암}

피오글리타존은 2011년 초 방광암의 위험성 문제 때문에 프랑스와 독일 시장에서 퇴출되거나 사용이 제한된 전력이 있 다. 또한 $\mathrm{FDA}$ 는 활동성 방광암 환자들에게 피오글리타존 제 제의 처방을 금지하였고, 방광암 발병 전력이 있는 환자들에 게 피오글리타존 제제를 처방할 때는 각별히 유의할 것을 권 고하고 있다. 방광암 위험과의 연관성에 대한 근거가 되는 연 구 중 PROactive 연구에서, 피오글리타존 복용군에서 더 많 은 방광암 환자가 발생하였지만, 위약군에서 발생한 한 명의 양성 종양을 제외하고서야 통계적으로 의미가 있었다. 2011 년 이후 PROactive 연장 연구결과에서는 위약 대비 피오글 리타존군에서 방광암 발생이 오히려 감소하는 경향을 보고 하기도 하였고, 19만여 명의 방광암 코호트연구에서는 방광
암 위험을 올리는 경향이었지만 통계적으로 유의하지 않았다 [33,34]. 하지만 미국과 프랑스에서 이루어진 역학 연구에서 2 년 이상 사용한 경우 방광암 발병의 위험성이 20 40\% 증가 하였고, 최근의 메타분석 연구 결과들에서도 피오글리타존의 방광암 발생과의 연관성을 제시하였다[35-38].

\section{5) 골절}

피오글리타존은 골밀도 감소 및 골절의 위험성을 증가시 킨다고 알려져 있으며, 그 중 PROactive study에서 남자 환 자는 피오글리타존 복용과 골절률과의 연관성이 없었으나, 여자 환자의 경우 피오글리타존 복용군에서 골절률이 $5.1 \%$ (44/870)로 대조군(2.5\%, 23/905)에 비하여 높았다. 2007년 $\mathrm{FDA}$ 에서는 여성 2형당뇨병 환자에서 피오글리타존을 포함 약제로 치료 중이거나 치료를 시작할 경우 골절 위험을 고려 해야 한다고 권고하였다. 특히, 폐경기 이후의 여성 환자에서 는 사지말단의 골절 위험성이 증가한다. $\operatorname{Lim}$ 등[39]은 로베 글리타존 복용 전에 비해 52주 후 허리와 골반의 골밀도를 감소시키지는 않았다고 보고하였다. 하지만 22 개의 연구를 종합한 메타분석에서 TZD를 사용한 여성에서 2 배의 골절 위 험도를 보였고[40], TZD의 사지말단의 골절 위험도는 중단 했을 경우 1 2년 사이 감소하였다(hazard ratio $=0.57 ; 95 \%$ CI 0.35 0.92) [41]. TZD에 의해 활성화된 PPAR- $\gamma$ 는 골수 에서 지방세포형성을 촉진하고, 골 생성을 감소시킨다. 그 외 에도 활동이 증가되는 파골세포의 분화, 골격근의 에너지 대 사에의 영향 등을 골밀도 감소 및 골절의 원인으로 제시하고 있다 $[42,43]$. 피오글리타존의 골절 위험성 증가에 대해서는 전 향연구도 진행되고 있어 그 결과 또한 관심을 기울일 필요가 있겠다.

\section{결론}

$\mathrm{TZD}$ 는 지방조직, 간, 근육에서 인슐린저항성을 개선시키고 포도당생성을 억제하면서 췌장 보호 효과를 가지는 인슐린민 감제로서, 혈당 개선효과 및 지속성, 낮은 저혈당 위험, 심혈 관계 안전 및 예방 효과, 지질대사 관점에서의 이익, 당뇨병 예 
방 및 최근 지방간, 치매에서 장점을 가지고 있지만, 체액저류/ 부종/심부전 및 방광암과 골절의 우려도 있다. TZD는 위험 대비 이득을 고려하면 여전히 중요한 득이 실보다 많은 유용 한 약제 치료 옵션이 될 수 있겠으며, 위험성을 고려하여 적절 한 선택 및 대처가 필요하겠다.

\section{REFERENCES}

1. Korean Diabetes Association. Diabetes. 5th ed. Seoul: Korean Diabetes Association; 2017. p401-3.

2. Korean Diabetes Association. Treatment guideline for diabetes. 6th ed. Seoul: Korean Diabetes Association; 2019. p57-64.

3. Ahmadian M, Suh JM, Hah N, Liddle C, Atkins AR, Downes M, et al. PPAR $\gamma$ signaling and metabolism: the good, the bad and the future. Nat Med 2013;19:557-66.

4. Finegood DT, McArthur MD, Kojwang D, Thomas MJ, Topp BG, Leonard T, et al. Beta-cell mass dynamics in Zucker diabetic fatty rats. Rosiglitazone prevents the rise in net cell death. Diabetes 2001;50:1021-9.

5. Zeender E, Maedler K, Bosco D, Berney T, Donath MY, Halban PA. Pioglitazone and sodium salicylate protect human beta-cells against apoptosis and impaired function induced by glucose and interleukin-1beta. J Clin Endocrinol Metab 2004;89:5059-66.

6. Gastaldelli A, Ferrannini E, Miyazaki Y, Matsuda M, Mari A, DeFronzo RA. Thiazolidinediones improve betacell function in type 2 diabetic patients. Am J Physiol Endocrinol Metab 2007;292:E871-83.

7. Kahn SE, Haffner SM, Heise MA, Herman WH, Holman RR, Jones NP, et al. Glycemic durability of rosiglitazone, metformin, or glyburide monotherapy. N Engl J Med 2006;355:2427-43.

8. Scherbaum WA, Göke B. Metabolic efficacy and safety of once-daily pioglitazone monotherapy in patients with type 2 diabetes: a double-blind, placebo-controlled study. Horm Metab Res 2002;34:589-95.

9. Einhorn D, Rendell M, Rosenzweig J, Egan JW, Mathisen AL, Schneider RL. Pioglitazone hydrochloride in combination with metformin in the treatment of type 2 diabetes mellitus: a randomized, placebo-controlled study. The Pioglitazone 027 Study Group. Clin Ther 2000;22:1395-409.

10. Rosenstock J, Einhorn D, Hershon K, Glazer NB, Yu S; Pioglitazone 014 Study Group. Efficacy and safety of pioglitazone in type 2 diabetes: a randomised, placebocontrolled study in patients receiving stable insulin therapy. Int J Clin Pract 2002;56:251-7.

11. Berhanu P, Perez A, Yu S. Effect of pioglitazone in combination with insulin therapy on glycaemic control, insulin dose requirement and lipid profile in patients with type 2 diabetes previously poorly controlled with combination therapy. Diabetes Obes Metab 2007;9:51220.

12. Kim SG, Kim DM, Woo JT, Jang HC, Chung CH, Ko KS, et al. Efficacy and safety of lobeglitazone monotherapy in patients with type 2 diabetes mellitus over 24-weeks: a multicenter, randomized, double-blind, parallel-group, placebo controlled trial. PLoS One 2014;9:e92843.

13. Jin SM, Park CY, Cho YM, Ku BJ, Ahn CW, Cha BS, et al. Lobeglitazone and pioglitazone as add-ons to metformin for patients with type 2 diabetes: a 24-week, multicentre, randomized, double-blind, parallel-group, active-controlled, phase III clinical trial with a 28 -week extension. Diabetes Obes Metab 2015;17:599-602.

14. Lim S, Ku EJ, Lee SY, Lee JH, Lee JE, Kim KM, et al. Therapeutic efficacy and safety of initial triple combination of metformin, sitagliptin, and lobeglitazone in drug-naïve patients with type 2 diabetes: initial triple study. BMJ Open Diabetes Res Care 2020;8:e000807. 
15. Dormandy JA, Charbonnel B, Eckland DJ, Erdmann E, Massi-Benedetti M, Moules IK, et al. Secondary prevention of macrovascular events in patients with type 2 diabetes in the PROactive Study (PROspective pioglitAzone Clinical Trial In macroVascular Events): a randomised controlled trial. Lancet 2005;366:1279-89.

16. Kernan WN, Viscoli CM, Furie KL, Young LH, Inzucchi SE, Gorman M, et al. Pioglitazone after ischemic stroke or transient ischemic attack. N Engl J Med 2016;374:132131.

17. Melmed S, Koenig R, Rosen C, Auchus R, Goldfine A, Williams R. Williams textbook of endocrinology. 14th ed. Philadelphia: Elsevier; 2019. p1371-402.

18. Yki-Järvinen H. Thiazolidinediones. N Engl J Med 2004;351:1106-18.

19. Goldberg RB, Kendall DM, Deeg MA, Buse JB, Zagar AJ, Pinaire JA, et. al. A comparison of lipid and glycemic effects of pioglitazone and rosiglitazone in patients with type 2 diabetes and dyslipidemia. Diabetes Care $2005 ; 28: 1547-54$.

20. Chalasani N, Younossi Z, Lavine JE, Charlton M, Cusi $\mathrm{K}$, Rinella $\mathrm{M}$, et al. The diagnosis and management of nonalcoholic fatty liver disease: practice guidance from the American Association for the Study of Liver Diseases. Hepatology 2018;67:328-57.

21. Belfort R, Harrison SA, Brown K, Darland C, Finch J, Hardies J, et al. A placebo-controlled trial of pioglitazone in subjects with nonalcoholic steatohepatitis. N Engl J Med 2006;355:2297-307.

22. Boettcher E, Csako G, Pucino F, Wesley R, Loomba R. Meta-analysis: pioglitazone improves liver histology and fibrosis in patients with non-alcoholic steatohepatitis. Aliment Pharmacol Ther 2012;35:66-75.

23. Aithal GP, Thomas JA, Kaye PV, Lawson A, Ryder SD, Spendlove I, et al. Randomized, placebo-controlled trial of pioglitazone in nondiabetic subjects with nonalcoholic steatohepatitis. Gastroenterology 2008;135:1176-84.

24. Choung S, Joung KH, You BR, Park SK, Kim HJ, Ku BJ. Treatment with lobeglitazone attenuates hepatic steatosis in diet-induced obese mice. PPAR Res 2018;2018:4292509.

25. Lee YH, Kim JH, Kim SR, Jin HY, Rhee EJ, Cho YM, et al. Lobeglitazone, a novel thiazolidinedione, improves nonalcoholic fatty liver disease in type 2 diabetes: its efficacy and predictive factors related to responsiveness. J Korean Med Sci 2017;32:60-9.

26. Watson GS, Peskind ER, Asthana S, Purganan K, Wait C, Chapman D, et al. Insulin increases CSF Abeta42 levels in normal older adults. Neurology 2003;60:1899-903.

27. Heneka MT, Fink A, Doblhammer G. Effect of pioglitazone medication on the incidence of dementia. Ann Neurol 2015;78:284-94.

28. DREAM (Diabetes REduction Assessment with ramipril and rosiglitazone Medication) Trial Investigators, Gerstein HC, Yusuf S, Bosch J, Pogue J, Sheridan P, et al. Effect of rosiglitazone on the frequency of diabetes in patients with impaired glucose tolerance or impaired fasting glucose: a randomised controlled trial. Lancet 2006;368:1096-105.

29. DeFronzo RA, Tripathy D, Schwenke DC, Banerji M, Bray GA, Buchanan TA, et al.; ACT NOW Study. Pioglitazone for diabetes prevention in impaired glucose tolerance. $\mathrm{N}$ Engl J Med 2011;364:1104-15.

30. Guan Y, Hao C, Cha DR, Rao R, Lu W, Kohan DE, et al. Thiazolidinediones expand body fluid volume through PPARgamma stimulation of ENaC-mediated renal salt absorption. Nat Med 2005;11:861-6.

31. Erdmann E, Charbonnel B, Wilcox RG, Skene AM, MassiBenedetti M, Yates J, et al.; PROactive Investigators. Pioglitazone use and heart failure in patients with type 2 diabetes and preexisting cardiovascular disease: data 
from the PROactive study (PROactive 08). Diabetes Care 2007;30:2773-8.

32. Sinha B, Ghosal S. Assessing the need for pioglitazone in the treatment of patients with type 2 diabetes: a metaanalysis of its risks and benefits from prospective trials. Sci Rep 2020;10:15781.

33. Erdmann E, Song E, Spanheimer R, van Troostenburg de Bruyn AR, Perez A. Observational follow-up of the PROactive study: a 6-year update. Diabetes Obes Metab 2014; 16:63-74.

34. Lewis JD, Habel LA, Quesenberry CP, Strom BL, Peng T, Hedderson MM, et al. Pioglitazone use and risk of bladder cancer and other common cancers in persons with diabetes. JAMA 2015;314:265-77.

35. Neumann A, Weill A, Ricordeau P, Fagot JP, Alla F, Allemand H. Pioglitazone and risk of bladder cancer among diabetic patients in France: a population-based cohort study. Diabetologia 2012;55:1953-62.

36. Tseng CH. Pioglitazone and bladder cancer in human studies: is it diabetes itself, diabetes drugs, flawed analyses or different ethnicities? J Formos Med Assoc 2012;111:123-31.

37. Tang H, Shi W, Fu S, Wang T, Zhai S, Song Y, et al.
Pioglitazone and bladder cancer risk: a systematic review and meta-analysis. Cancer Med 2018;7:1070-80.

38. Filipova E, Uzunova K, Kalinov K, Vekov T. Pioglitazone and the risk of bladder cancer: a meta-analysis. Diabetes Ther 2017;8:705-26.

39. Lim S, Kim KM, Kim SG, Kim DM, Woo JT, Chung CH, et al. Effects of lobeglitazone, a novel thiazolidinedione, on bone mineral density in patients with type 2 diabetes mellitus over 52 weeks. Diabetes Metab J 2017;41:37785.

40. Zhu ZN, Jiang YF, Ding T. Risk of fracture with thiazolidinediones: an updated meta-analysis of randomized clinical trials. Bone 2014;68:115-23.

41. Schwartz AV, Chen H, Ambrosius WT, Sood A, Josse RG, Bonds DE, et al. Effects of TZD use and discontinuation on fracture rates in ACCORD bone study. J Clin Endocrinol Metab 2015;100:4059-66.

42. Wan Y, Chong LW, Evans RM. PPAR-gamma regulates osteoclastogenesis in mice. Nat Med 2007;13:1496-503.

43. Jeyabalan J, Shah M, Viollet B, Chenu C. AMP-activated protein kinase pathway and bone metabolism. J Endocrinol 2012;212:277-90. 